\title{
Dr William Wilson Ingram (1888-1982): doctor-soldier, physician and Antarctic expeditioner
}

\author{
JH Pearn \\ Preceptor, School of Medicine, University of Queensland, Brisbane, Australia
}

\begin{abstract}
Dr William Wilson Ingram (1888-1982), a Scottish-born physician, contributed significantly to the health and heritage of Australia, his adopted land. Born on Speyside and educated in Aberdeen, he was a doctor-soldier in two World Wars and decorated with the Military Cross. Ingram was a Foundation Fellow (1938) of the Royal Australasian College of Physicians and established one of the first specialist diabetic clinics in Australia, in Sydney in 1928. As an arachnologist, he published clinical descriptions of both surviving and fatal cases of envenomation by the Sydney funnel web spider, Atrax robustus. He founded the Kolling Institute of Medical Research at the Royal North Shore Hospital in Sydney where for two generations he was a leader in both undergraduate and postgraduate medical education. The international significance of his life's work relates to his service as the medical officer and biologist on the two British, Australian and New Zealand Antarctic Research Expeditions (BANZARE) of 1929-1931, for which service he was awarded the Polar Medal and subsequent Clasp. Those expeditions secured, for the British Crown, what was to become the Australian Antarctic Territory, ceded to Australia by a British Order in Council of 24 August 1936. Sir Douglas Mawson, polar expeditioner and the leader of BANZARE, described Ingram as 'an ideal medical officer', one who in addition to his clinical skills and judgement, manifested courage and 'physical endurance and a full measure of camaraderie'. Ingram has no published obituary or biography. This précis records some details of his extraordinary life.
\end{abstract}

KEYWORDS WW Ingram (I888-1982), Antarctica, polar exploration, military medicine, diabetes

DECLARATION OF INTERESTS No conflict of interests declared.

\author{
Correspondence to JH Pearn, \\ History \& Heritage, \\ Royal Children's Hospital, \\ Brisbane Queensland 4029, \\ Australia
}

\author{
tel. +61733655323 \\ e-mail \\ j.pearn@uq.edu.au
}

In a paper read at the Royal Geographical Society in London on 7 March 1932,' Sir Douglas Mawson (18821958) referred to the exemplary service of his Medical Officer, Dr William Wilson Ingram. ${ }^{2}$ The paper was a summary of the two British,Australian and New Zealand Antarctic Research Expeditions (BANZARE) of 19291930 and 1930-1931.3,4

The expeditions, driven both by geopolitics and science, were funded by the British, Australian and New Zealand governments and by private philanthropy. On these journeys, Sir Douglas Mawson laid claim for the British Crown to what was to become the Australian Antarctic Territory, formalised in 1933 in the Australian Antarctic Territory Acceptance Act. ${ }^{5}$ Mawson described his medical officer in the following terms:

In Dr Ingram, the Expedition was most fortunate for there could have been no more ideal medical officer for such an undertaking, where scientific research is linked with hazard, and demands of physical endurance and a full measure of camaraderie. ${ }^{6}$
In 1928, when he was recruited for the expedition, Dr 'Bill' Ingram was a highly decorated doctor-soldier from the First World War, ${ }^{7}$ and a consultant physician in specialist practice in Macquarie Street, Sydney. ${ }^{8-10}$ From 1920 he had been an influential and innovative Honorary Pathologist, medical research advocate" and Honorary Physician at the Royal North Shore Hospital, one of Sydney's leading teaching hospitals. ${ }^{8}$ Ingram had undertaken postgraduate research in anatomy, pathology, biochemistry and physiology, ${ }^{8,9}$ and had evinced a practical interest in natural history. ${ }^{12}$

He established one of the first clinics for the treatment of diabetes and wrote the first textbook on diabetes and its management in his adopted country. His manifest clinical skills and research bent, combined with an engaging but forceful personality, characterised his persona (Figure I). It was these features which Mawson described as those of an 'ideal medical officer'. ${ }^{6}$ This paper reviews these criteria as evidenced throughout $\mathrm{Dr}$ William Wilson Ingram's extraordinary life. 


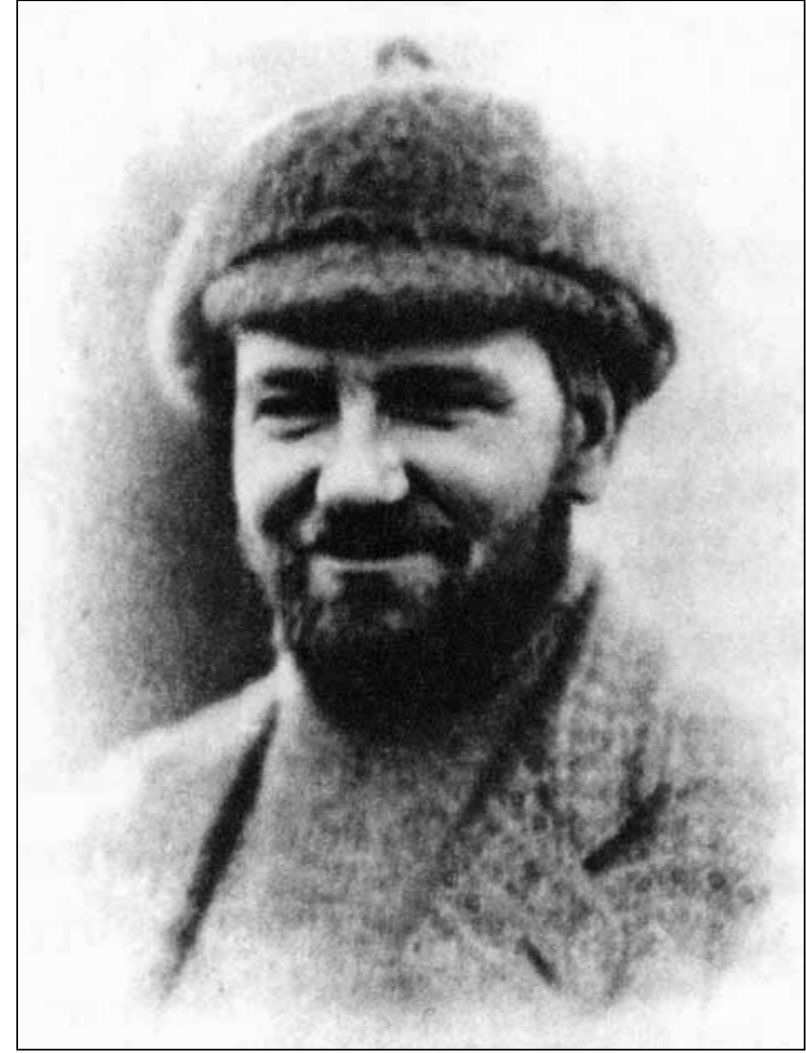

FIGURE I DrWilliam Wilson Ingram (1888-1982) during the first BANZARE Expedition (1929-1930) en route to Antarctica. Photograph by Frank Hurley, courtesy of the Australian Antarctic Division, Kingston, Tasmania.

\section{EARLY LIFE}

William Wilson Ingram was born on 6 December 1888 , beside the River Spey in the village of Craigellachie, in what was then West Banffshire. His father, James Ingram, was the newspaper editor in the distillery village of Dufftown, four miles to the southwest. William went to school at Robert Gordon's College in Aberdeen, matriculated and studied medicine at the University of Aberdeen.' He graduated in 1912 and worked at the Royal Aberdeen Hospital for Sick Children and from 19/3 was employed for 18 months as a Research Assistant (to Sir Edward Holt) at the Lister Institute in London. ${ }^{13}$

\section{A DOCTOR-SOLDIER}

When World War One was declared, Dr Ingram immediately enlisted in the Royal Army Medical Corps on I September 1914, in the tradition of Highland doctors. He was commissioned as a Temporary Lieutenant and was posted as a Regimental Medical Officer with the Royal Scots Fusiliers. Within weeks of service he was Mentioned in Despatches. On 18 February 1915 Lieutenant Ingram was awarded the Military Cross, this latter approved by Field Marshal French for gallant and distinguished services in the field. ${ }^{13}$
He was wounded in action in 1915 and invalided to London. After recovery he worked in Mount Vernon Hospital, London, then a military hospital where Sir William Osler (1849-1919) was the senior clinician. During his convalescence, Ingram worked for six months as House Officer to Osler. He was promoted to Captain in September $1915^{7}$ and in 1916 returned to France and was posted to No. I I General Hospital. For a period he was attached as a Regimental Medical Officer to the 10th Dragoon Guards before being finally posted as Officer Commanding Pathology Services at the Headquarters of the British Expeditionary Force. ${ }^{7}$ Captain Ingram remained in uniform for six months after the Armistice of November 1918 and finally relinquished his commission with the retained rank of Captain in May 1919.7 He returned to Aberdeen and was appointed Lecturer in Anatomy in which post he undertook research for his Doctorate of Medicine, awarded with Honours in 1919.14

\section{A SYDNEY PHYSICIAN}

Dr Ingram decided to travel, and 'stopped over in Sydney'. ${ }^{8}$ There he obtained an appointment as Lecturer in Professor Henry Priestley's (1884-1961) Department of Biochemistry at the University of Sydney.' In 1920, Ingram established a general medical practice at his home in Killara, a northern Sydney suburb. The practice flourished and he was joined by two assistants with whom he worked for the ensuing seven years. In 1921, he was approached by the Board of the Royal North Shore Hospital offering him an appointment as foundation Honorary Pathologist with a view to establishing a pathology service at what was one of Sydney's largest teaching hospitals. He began a crusade to establish not only a leading pathology service, but also a research institute. Ingram stated in his appointment submission that 'preventive medicine must be associated with curative medicine'. ${ }^{8}$ He established the Institute of Pathological Research in 1923, using his experience at the Lister Institute in London as his administrative model. A rich American businessman, Charles Kolling, had commercial interests in North Sydney and his major bequest made Ingram's Research Institute possible. Extended and renamed, the Kolling Institute of Medical Research was opened in August 1931 by Sir Phillip Game, Governor of New South Wales.

Ingram had become particularly interested in clinical biochemistry. In that era, senior clinical appointments at Australian public hospitals were honorary appointments and Ingram was appointed Honorary Assistant Physician to Royal North Shore Hospital in 1925. He returned to London and undertook a year's postgraduate study initially working with Lord Dawson (1864-1945) at The London Hospital and subsequently with Professor Hugh Maclean (d I 974) at St Thomas's Hospital. Insulin had been discovered four years earlier in 1921 and by mid-1922 


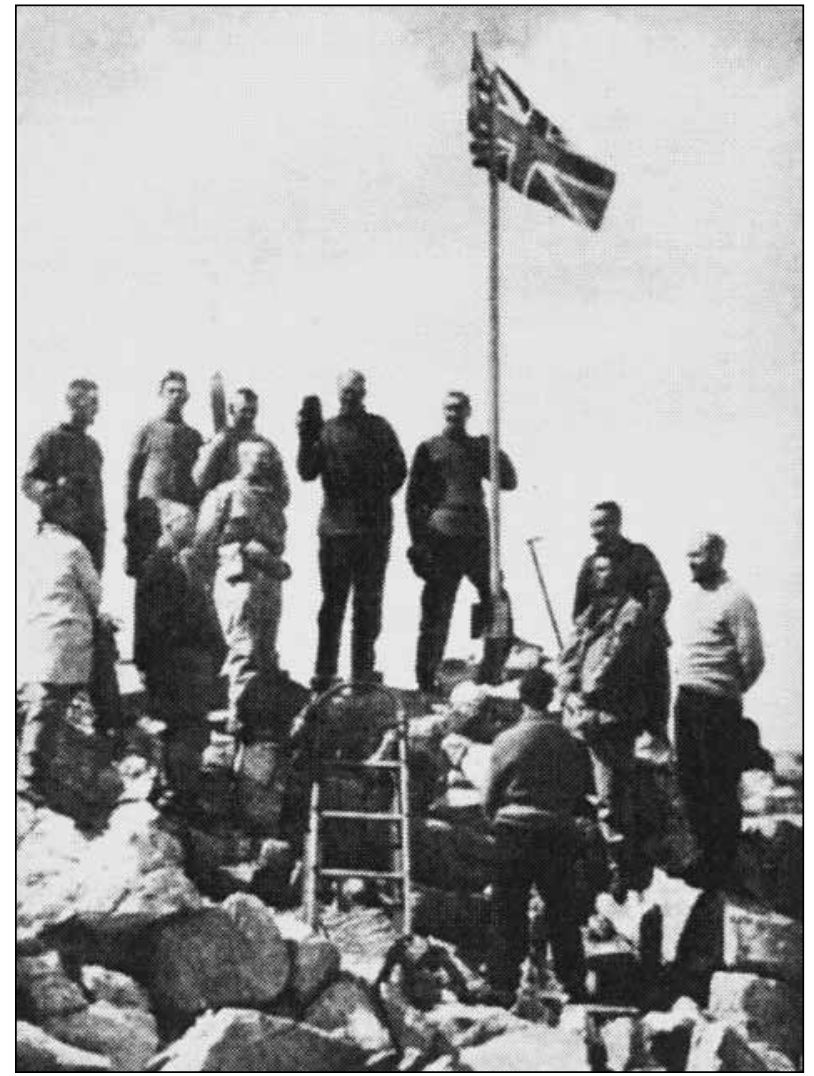

FIGURE 2 The formal claim for Enderby Land, in Antarctica, made by Sir Douglas Mawson on behalf of the British Crown, 'at the hour of noon' on 12 January 1930. Sir Douglas Mawson and the expedition doctor, DrWilliam Wilson Ingram are in the photograph. Photograph courtesy of the State Library of South Australia.

news of the dramatic effects of insulin had reached both the medical and popular press. It was said that 'Almost overnight the lot of the diabetic patient was changed from a sentence of almost certain death to a prospect not only of survival but of being able to lead a long and healthy life'. ${ }^{15}$ Dr Ingram's experience with what was still regarded as a miracle cure, at one of the epicentres of diabetic research in the United Kingdom in that exciting era, was the genesis of his lasting interest in the treatment of diabetes. He returned to Sydney in 1926 and established one of the first specialist diabetic clinics in Australia. In 1927 he left general practice to specialise in internal medicine, acquiring rooms in Macquarie Street, the 'Harley Street' of Sydney.

\section{AN ANTARCTIC EXPEDITIONER}

In 1909, during Shackleton's British Antarctic Expedition on the Nimrod (1907-1909), Mawson, together with Edgeworth David (1858-1934) and the expedition Assistant Surgeon, another Scot, Alistair Forbes Mackay (1878-1914), had been the first to reach the South Magnetic Pole. ${ }^{5}$ After that epic Expedition, Sir Edgeworth David (Professor of Geology at Sydney University from I89I to 1934), had kept closely in touch with Sir Douglas
Mawson, Professor of Geology and Mineralogy at the University of Adelaide. In the context of the initial planning (1928) for the BANZARE expeditions, Edgeworth David approached Ingram to consider the position of Medical Officer and Biologist for the proposed expeditions on board RRS Discovery. ${ }^{3,49}$

Polar exploration, where the threat to life and limb is great, depends appreciably on medical support. Success has always depended on overcoming the risks of shipwreck, drowning, trauma, hypothermia, cold injury, starvation, hypervitaminosis $A$ and the psychological challenges of the polar world. Doctors supporting such exploration needed special qualities. In this context, Sir Douglas Mawson chose Dr Ingram as the BANZARE medical officer, following Sir Edgeworth David's recommendation. William Ingram, well known for his gregarious nature and his infectious camaraderie, ${ }^{6}$ was a popular member of the all-weather Albatross Swimming Club and the Killara Golf Club, both in North Sydney. In 1929, the Killara Golf Club held a Tribute Dinner to say farewell to their popular local doctor. Ingram had always manifested his pride in his Scottish heritage by his dress and conversation and so a poem, entitled 'Wee Willie Winkie' to be sung to the tune of the refrain of Bonnie Dundee, was composed to be read at the dinner in Dr Ingram's honour, before he left for Antarctica. Selected verses were:

Noo Wee Willie Winkie is gangin' awa'

Farewell tae the Kilties and spooran an' a

Tis troos he maun wear where the icy wind blows

That wad freeze a' the tips off a brass monkey's toes.

As wild as a warrigal out of the Scrub

Is Wee Willie Wink of the Albatross Club

Oh happy is he where the lazy waves roll

But he'll never go swimming down there at the Pole.

Oh Wee Willie Winkie when down in the south

With icicles strung on the hair round your mouth

Will you think of us sometimes and picture as here

With sweat on our foreheads and ice in our beer.

Poor Wee Willie Winkie, in Eskimo guise

You'll go till again you will gladden our eyes,

Then doon with troosers that tickle the knee

And up wi' the bonnets o' Bonnie Dundee. ${ }^{16}$

Dr Ingram then journeyed to Hobart and met with the RRS Discovery team.

\section{THE BANZARE EXPEDITIONS |929-|93|}

Britain had first laid formal claim to a major part of Antarctica in Letters Patent of 21 July 1908. The purpose of the BANZARE voyages was an 'acquisitive exploratory expedition' to enforce formal claims of British sovereignty over this vast area of the Antarctic land mass. ${ }^{17}$

The Discovery left Hobart on 19 October 1929. The expedition visited Kerguelen Island on the 12 November 


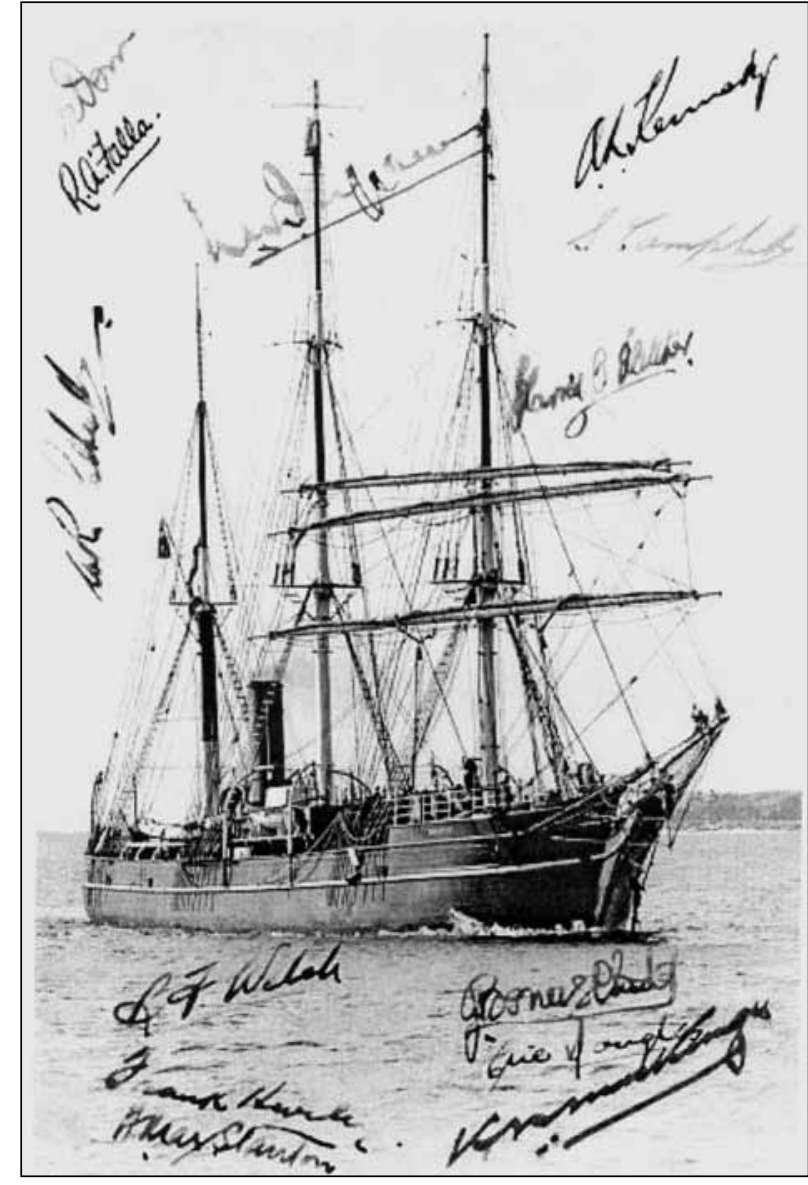

FIGURE 3 A souvenir sheet of RRS Discovery in the Derwent River, Hobart, on return from the BANZARE Expedition in 1930. DrWilliam Wilson Ingram's signature is at the top of the main mast of the steam barque. Photograph courtesy of the Ingram Collection, Royal Australasian College of Physicians.

where rabbits and sledging dogs left by former whalers and sealers had wreaked ecological havoc. ${ }^{18}$ On 12 January 1930 the expedition landed at Cape Batterbee on the northern tip of Antarctica, where Mawson recorded:

At the hour of noon the Union Jack was hoisted thereon and a proclamation was read ... the whole of Enderby Land... As far west as 47 degrees of East longtitude... were claimed for the British Crown. ${ }^{19}$ [Figure 2.]

Another Union Jack was dropped from the air on the Antarctic land mass on 25 January 1930, and a proclamation read claiming territory between $45^{\circ} \mathrm{E}$ and $56^{\circ} \mathrm{E}$, the present day Enderby Land in the Australian Antarctic Territory. ${ }^{20}$ The expedition returned to Kerguelen on 8 February and sailed to Albany in Western Australia on 21 March. ${ }^{21}$ Upon reaching Melbourne, a number of the crew members and expeditioners left and were replaced, but Dr Ingram stayed with Mawson. During the winter of 1930, the Discovery was refitted at the Williamstown Dockyards in Melbourne.

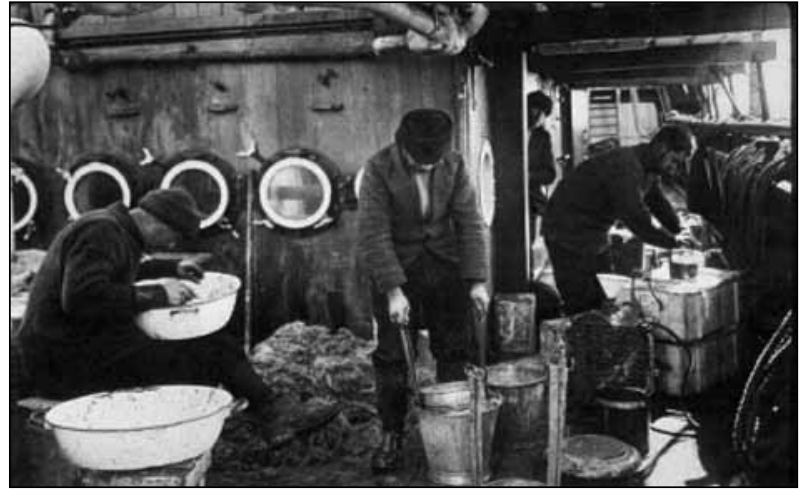

FIGURE 4 DrWilliam Wilson Ingram, centre, placing krill specimens in a collecting bucket, on board RRS Discovery on the first BANZARE Expedition 1929-1930. Photograph by Frank Hurley, 1929. Courtesy of the State Library of South Australia. P SLSA: B55766.

On the Second BANZARE expedition (1930-193I), the Discovery left Hobart on 22 November 1930, arriving at Macquarie Island on 2 December. Dr Ingram was photographed with a 'dead sea elephant and skua gulls' at Macquarie Island. ${ }^{22}$ The Discovery encountered fearful gales, and on New Year's Day I93I, Mawson described a gale which

... developed into a furious hurricane which lasted several days: the ship was forced back into the pack ice with which she drifted to the west for about 50 miles, and at times her position became critical. ${ }^{23}$

The expedition sailed south through pack ice to Adelie Land. On 4 January 1931, the Discovery anchored off Cape Denison on the coast of King George V Land. There Mawson hoisted the Union Jack and a proclamation was read on 5 January:

At noon on the 5th [January 193I] the flag was hoisted on a rocky point overlooking the bay. In a casket at the foot of the pole a proclamation was deposited, claiming formal possession of King George $V$ Land, defined as that Section of the Antarctic Coast-line extending between the 142nd and the 160th degree of east longitude. ${ }^{24}$

MacRobertson Land was sighted and named in the second week of February 1931.The expedition had been mounted at the time of the Great Depression and although partly funded by the British, Australian and New Zealand governments, the enterprise was made possible only by the philanthropy of:

... a patriotic and generous [Scottish] citizen of the Commonwealth, Mr MacPherson Robertson, popularly known as 'MacRobertson' [who] came to our assistance with the princely sum of $£ 10,000$. This he subsequently greatly augmented in order to make possible the continuance of the work (of BANZARE) for a second year. ${ }^{2}$ 


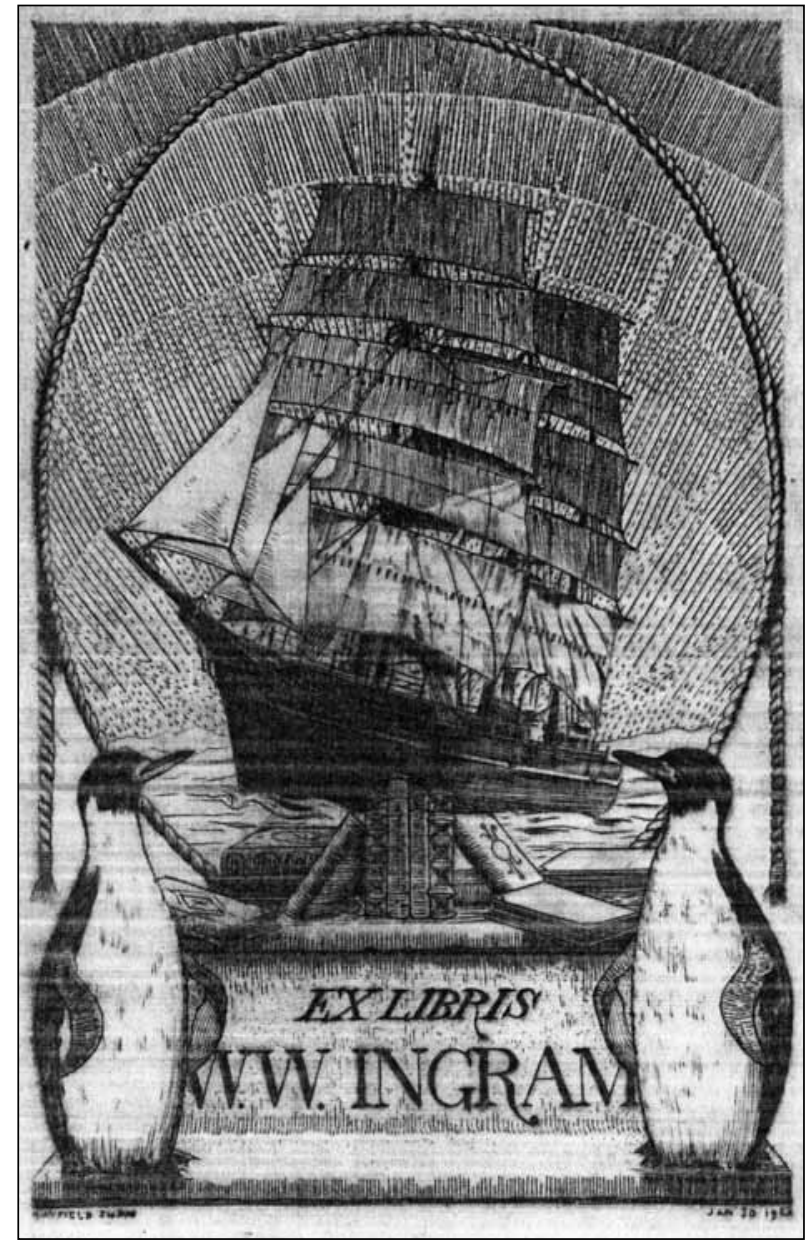

FIGURE 5 The bookplate of DrWilliam Wilson Ingram, consultant physician of Sydney and Antarctic expeditioner. The generic ship portrayed is a composite of two of the Polar expedition vessels, the steam barques, Aurora and Discovery, under full sail. Photograph courtesy of the Royal Australasian College of Physicians.

In March 193I, RRS Discovery became stuck in the pack ice for a period of three weeks. The doctor and scientists exploited this period for scientific research. ${ }^{25}$

On the voyage 'Biological observations were given a very prominent place in the expedition programme'. ${ }^{26} \mathrm{Dr}$ Ingram's work is mentioned by others, especially his biological work and his role 'as one of the Discovery veterans who pioneered studies of Antarctic krill'. ${ }^{27}$ In recent decades, the role of the 1929-31 Discovery researches on krill, in which the capturing nets were opened and closed at chosen depths accurately recorded by a 'primitive depth sounder' is afforded particular significance in the context of accurate understanding of the biota of the world's oceans. ${ }^{27}$ The Discovery completed her voyage on arrival at Hobart on 19 March $\left.193\right|^{28}$ (Figure 3). On the two expeditions, Dr Ingram assisted with the scientific collections among which 'special attention was given to the study of plankton, both in its horizontal and vertical distribution'25 (Figure 4). Dr Ingram also conducted some bacteriological investigations. Following the BANZARE voyages, the Australian Antarctic Territory Acceptance Act 1933 was passed in Canberra. ${ }^{29}$ It was followed by the British Government ceding to Australia the Territory it had claimed on 24 August 1936..$^{30}$ For his medical and scientific service on the two expeditions, Dr Ingram was decorated with the Polar Medal and Clasp. ${ }^{10}$

Dr Ingram did not publish any formal accounts of his work in Antarctica in the medical press, but an extensive archive of his notes and other memorabilia is held in the Mitchell Library, Sydney and at the Royal Australasian College of Physicians (Figure 5).

\section{PHYSICIAN AND PATHOLOGIST}

Following his return from Antarctica in 1931, Dr Ingram re-entered clinical practice with vigour. ${ }^{8}$ Based at his consulting rooms at 'Craignish' at 185 Macquarie Street in Sydney, he treated both adults and children and took an active part in the clinical affairs of the New South Wales Branch of the British Medical Association in Sydney.

In August 1931 he published a clinical paper on Arachnodactyly associated with muscular hypotonia' which was almost certainly a Marfan syndrome variant. In 1933 he presented and published the case of a 43-year-old truck driver with 'driver's thigh', an occupational rightsided sciatic-nerve lesion with secondary muscle wasting. Ingram opined that this was due to 'faulty construction of the driver's seat in his motor vehicle'. ${ }^{32}$ In 1933 he also published a major paper on spider envenomation, including three cases, one fatal, of funnel web spider bite, which he had treated personally. ${ }^{33}$ This paper was published with colour illustrations, one of the first in Australian medical journals to include these. ${ }^{34}$ The title of the paper, Spider bite (arachnidism), had a delightful synergy, perhaps intended, with his 1931 paper entitled Arachnodactyly. ${ }^{31}$

Ingram served on the Special Medical Committee, commissioned by the New South Wales State Government in 1936, to audit the claimed clinical benefits of the Kenny Method of treating poliomyelitis, being carried out in the Elizabeth Kenny Clinic at the Royal North Shore Hospital..$^{35} \mathrm{He}$ disagreed with the theories claimed by Sister Elizabeth Kenny for her clinical success but 'they remained good friends'. ${ }^{8}$

Dr Ingram served the Royal North Shore Hospital in Sydney with dedication. With the exception of his time away on the BANZARE expeditions and on active service in World War Two, he served the Hospital for 57 continuous years, of which 33 years were as a Senior Honorary Physician. ${ }^{8}$ Together with Sir Norman Nock (1899-1990) and Dr Wallace Freeborn (1898-197I) he established the Hospital Clinical School which was opened in 1948; he established the Hospital's library and served as the foundation Hospital Librarian from 1931 for 
four decades. Ingram was elected as the first Chairman of the Hospital's Board of Medical Studies (1948-1974), served as Director of Pathology Services (1922-1965), as Director of the Kolling Institute of Medical Research (1931-1974) and latterly as Chairman of the Honorary Medical Staff at the Royal North Shore Hospital. The Wilson Ingram Conference Room at Royal North Shore Hospital commemorates his life and works. ${ }^{36}$

\section{A PIONEER ENDOCRINOLOGIST}

Dr Ingram's most significant contributions to clinical medicine were in the field of diabetes. His postgraduate background in clinical biochemistry in London was particularly relevant in this context. Within a year of the discovery in 1921 that a lack of endogenous insulin was the cause of diabetes, ${ }^{15}$ clinicians throughout the world began to treat patients with the new wondrous hormone. The first experimental use of insulin in Australia was an attempt to save the life of a six-year-old girl in North Sydney in late 1922.37 Insulin was prepared at the Commonwealth Serum Laboratories in Melbourne from January $1923^{38}$ and the clinical use of insulin to treat diabetes was reported by Professor John Wilkinson in Melbourne in June 1923. ${ }^{39}$ Most physicians treated diabetic patients as part of their general medical practice, but Dr Ingram, in 1928, established one of the first specialist Diabetic Clinics in Australia at Royal North Shore Hospital. He lectured extensively on diabetes ${ }^{40}$ and published pamphlets and booklets about its management. These included such titles as Diabetes in the Young, ${ }^{41}$ Diabetic Diets, ${ }^{42}$ and The Management of Diabetic Pre-Coma and Coma. ${ }^{43}$

In 1933, with Dr GV Rudd, Ingram wrote the major text The Diagnosis and Treatment of Diabetes, published by Angus and Robertson ${ }^{44}$ which passed through four editions, the last in $1943 .{ }^{45}$

\section{A REMARKABLE PERSONALITY}

In December 1936 Dr Ingram married Dorothy King, the Nurse-in-Charge of his Diabetic Clinic at the Royal North Shore Hospital. He was 48 years of age at the time, and it proved to be an enduring, loving, 'fun-filled' marriage. ${ }^{8}$ The couple had no children.

At the outbreak of World War Two, Ingram re-enlisted in the Australian Army Medical Corps and was appointed a temporary Lieutenant Colonel. He was immediately posted as Officer Commanding the Medical Division of I 9 Australian General Hospital. His rank, as substantive Lieutenant Colonel was confirmed on I September 1942 and he served as Officer Commanding the Medical Divisions, successively of 102 and I 04 Australian General Hospitals, serving in Darwin during the Japanese bombing raids of $1942 .{ }^{46}$
Dr Ingram's robust personality and his eschewing of petty officialdom did not sit well with authority, especially with some younger military officers of senior rank. Colonel Ingram 'captured' a General and his headquarters staff during a training exercise near Darwin, an act about which 'the Commanding General was not amused... and he was one of the few people who never forgave me'. ${ }^{47}$ In June 1944, Ingram had an altercation with his Commanding Officer of 102 Australian General Hospital, a culmination of disagreements about restrictions while the Hospital was sited near Taree in New South Wales. Colonel Ingram was on first name terms with 'Billy' Hughes, a member of the War Advisory Council. Ingram telephoned Hughes from the Officers' Mess, and resigned his commission with immediate effect. ${ }^{47}$

Dr Ingram continued his remarkable life, remaining in active clinical practice as a specialist physician until the age of 91 years. He had been an active member of the Albatross Swimming Club in Sydney, and was a member (Membership No. I19) of the Antarctic Club whose traditions in Australia later became those of the New South Wales Branch of the ANARE Club.

Esteemed both personally and professionally, Dr Wilson Ingram remained a vigorous personality at the Royal North Shore Hospital, where, on his 90th birthday 'at his very best', he unveiled a commemorative plaque in the Library at the Hospital which he had served for almost six decades. ${ }^{8}$ He died at home in his sleep aged 94 years - a man, who by any historical standard, satisfied Sir Douglas Mawson's criteria of 'an ideal medical officer'.

\section{Acknowledgements}

This research was made possible by the encouragement of Ms Liz Rouse, Librarian of the Library of the History of Medicine, the Royal Australasian College of Physicians, Sydney and Dr Peter Sullivan Antarctic Medal, of Tasmania. The photographs are from the Ingram Collection, courtesy of the Royal Australasian College of Physicians, Sydney; and also with permission from the Australian Antarctic Division, Kingston, Tasmania and the State Library of South Australia, Adelaide. 


\section{REFERENCES}

I NOTE: Sir Douglas Mawson's paper, summarising the 1929-193। BANZARE expeditions to the Antarctic, was read by Professor Debenham at an Evening Meeting of the Royal Geographical Society on 7 March 1932. The text of Mawson's address was published in the Society's Geographical Journal in August 1932. See reference 2 .

2 Mawson, Sir Douglas. The BANZ Antarctic Research Expedition, | 929-3 I.GeographicalJournal I 932;80: I0 |-26.doi: I0.2307/| 784070

3 Mawson, Sir Douglas [BANZARE Expedition Leader] and BANZARE Expedition Committee. BANZ Antarctic Research Expedition 1929-3 I Reports (I 3 volumes).Adelaide: Mawson Institute for Antarctic Research, University of Adelaide; 1937-1975.

4 Price AG. The Winning of Australian Antarctica: Mawson's BANZARE voyages, 1929-3I. Based on the Mawson Papers. Sydney: Angus and Robertson; 1962.

5 Jacka FJ. Mawson, Sir Douglas (1882-1958), geologist and explorer In: Nairn B, Serle G, editors. Australian Dictionary of Biography Vol 10. Melbourne: Melbourne University Press; 1986. p. 454-57.

6 Price A Grenfell. The Winning of Australian Antarctica. Mawson's BANZARE Voyages 1929-3I. Based on the Mawson Papers. Adelaide: Angus \& Robertson for the Mawson Institute for Antarctic Research, University of Adelaide; 1937. p. 161.

7 The War Office, United Kingdom. Military Service Record of Captain W.W. Ingram M.C., M.D. Records 24/I/I59 (R. Records). Letter for The War Office, Whitehall, London, of 21 January, 1937. Copy held in Archives, Library of the History of Medicine, Royal Australasian College of Physicians, Sydney.

8 Vanderfield IR. 'DrW.Wilson Ingram'. Text of the Address given by Dr I.R. Vanderfield, General Medical Superintendent at the Memorial Service held in the Royal North Shore Hospital Chapel, Monday 6 December 1982. Archives, Library of the History of Medicine, Royal Australasian College of Physicians, Macquarie Street, Sydney 2000. p. I-5.

9 Vanderfield IR. Ingram,William Wilson. Roll of the Royal Australasian College of Physicians. Vol II. 1976-1990. Hon. Eds. J.C. Wiseman, R.J. Mulhearn. Sydney: Royal Australasian College of Physicians; 1994. p. 162-63.

10 Knox EG. Ingram William Wilson M.C., M.D. Aberdeen (1919) (MBChB 1912), FRACP 1938 (Foundation). In: Medical Directory of Australia 1970. 14th Issue. Sydney:Australasian Medical Publishing Co. Ltd.; 1970. p. 403.

II Royal North Shore Hospital, Sydney. Institute of Medical Research Annual Report 197I-1973. p. 7.

I2 Ingram WW, Musgrave A. Spider bite (arachnidism): a survey of its occurrence in Australia, with case histories. Med J Aust 1933; 2:10-15.

13 [Editor]. London Gazette 18 February 1915.

14 [Editor]. Universities and Colleges. University of Aberdeen. [Graduation Lists] of July IIth [19/9]. M.D. with Honours for Thesis. W.W. Ingram. BMJ 1919; 2:94.

I5 Richardson RG. Discovery of Insulin and Cortisone. In Encyclopaedia Britannica. Macropaedia.Vol II. Chicago, Encyclopaedia Britannica Inc, 1974: 835.

16 [Anon] 'Wee Willie Winkie'. A poem 'to the tune of the refrain of Bonnie Dundee'. Recited at the Killara Golf Club, North Sydney, on 10 September 1929. Archival copy held in the Ingram Box, Library of the History of Medicine, Royal Australasian College of Physicians, Macquarie Street, Sydney.

17 Collis C. The Proclamation Island moment: making Antarctica Australian. Law Text Culture 2004; 8: I-18.

18 Mawson, Sir Douglas. The BANZ Antarctic Research Expedition, |929-31. Geographical Journal 1932; 80: 105. doi:I0.2307/I784070

19 Mawson, Sir Douglas. The BANZ Antarctic Research Expedition, 1929-31. Geographical Journal 1932; 80: I I0. doi: I0.2307/I784070

20 Mawson, Sir Douglas. The BANZ Antarctic Research Expedition, 1929-31. Geographical Journal 1932; 80: I I2. doi:10.2307/I784070

21 Mawson, Sir Douglas. The BANZ Antarctic Research Expedition, |929-31. Geographical Journal 1932; 80: I I3. doi:10.2307/I784070
22 Cultural Collections at the University of Newcastle, Australia. Photographs of second BANZ voyage to Antarctica 22 November 1930 to I9 March 1931, taken by W Howard, crew member of the Discovery. Image 006. Donated by J Downie, Mayfield. [Internet]. Australia: University of Newcastle; [cited 20II February 27]. Available at: http://uoncc.wordpress.com/2007/07/04/2ndbanzare-voyage-to-antarctica

23 Mawson, Sir Douglas. British Australian New Zealand Antarctic Research Expedition, 1930-31. Polar Record 1931; I:56-60. doi:10.1017/S003224740002935 I

24 Mawson, Sir Douglas. The BANZ. Antarctic Research Expedition, 1929-31. Geographical Journal 1932; 80:115. [Mawson here was referring to his $1911-14$ Expedition]. doi: $10.2307 / 1784070$

25 Mawson, Sir Douglas. The BANZ Antarctic Research Expedition, 192931. Geographical Journal 1932; 80:Appendix I-Scientific Results: I 23.

26 Cultural Collections at the University of Newcastle, Australia. Photographs of second BANZ voyage to Antarctica 22 November 1930 to 19 March 1931, taken by W Howard, crew member of the Discovery. Image 043. Donated by J Downie, Mayfield. [Internet]. Australia: University of Newcastle; [cited 20II February 27]. Available at: http://uoncc.wordpress.com/2007/07/04/2ndbanzare-voyage-to-antarctica

27 Nicol S, Brierley AS.Through a glass lens darkly - New approaches for studying the distribution, abundance and biology of Euphausüds [Antarctic krill]. Deep Sea Research Part II: Topical Studies in Oceanography 2010; 57:496-507. doi:I0.1016/j.dsr2.2009.10.002

28 Mawson, Sir Douglas. The BANZ Antarctic Research Expedition, 1929-31. Geographical Journal 1932; 80:123. doi:10.2307/I784070

29 NOTE:The Australian Antarctic Territory Acceptance Act 1933-An Act to Provide for the Acceptance of Certain Territory in the Antarctic Seas as a Territory under the Authority of the Commonwealth. The Act was Act No. 8 of 1933, as Amended to Act 216 of 1973.This Act comprised '... all the islands and territories, other than Adelie Land, situated south of the 60th degree south latitude and lying between the 160th degree east longitude and the 45th degree east longitude...' [Internet] [cited 20II March I] Available at: http:// www.austlii.edu.au/au/legis/cth/consol_act/aataa 1933407/ and http://www.comlaw.gov.au/Details/C2004C004I6

30 NOTE: Following this Australian Antarctic legislation of 1933, the British Government passed the Territory to the Australian Government, it having been claimed in $|930-3|$ by Sir Douglas Mawson in the name of the British Commonwealth. The British Government, in its Proclamation in an Order-in-Council of 24 August 1936 'placed the Australian Antarctic Territory under the authority of Australia'. See UK Government Gazette 1936: I I53; and UK Statutory Rules 190I-1956. Vol V: 5505.

3I Ingram WW. Arachnodactyly associated with muscular hypotonia. Med J Aust 1931; 2:238-40.

32 [Editor]. British Medical Association (New South Wales Branch). Case Presentation by Dr W.Wilson Ingram. Driver's Thigh. Med J Aust 1933; ii:802.

33 Ingram WW, Musgrave A. Spider bite (arachnidism): a survey of its occurrence in Australia, with case histories. Med JAust 1933; 2:10-15.

34 NOTE: The coloured illustration of both Atrax robustus (funnel web spider) and Latkodectus hasseltii (red back spider) were drawn by Miss EA King. Both species were drawn natural size, in exquisite almost photographic detail.

35 The Elizabeth Kenny Clinic, the Royal North Shore Hospital of Sydney. Report by Special Medical Committee [Chair WW Ingram] on the results obtained from the treatment of paralysis. Sydney: Government printed; 1937. p. I-6.

36 Brochure, printed on the Occasion of a Luncheon to Commemorate the Official Opening, by Dr W.Wilson Ingram, of Extensions to the Library of the Royal North Shore Hospital. 6 December 1978. Ephemera. Held in the Ingram Box (Item II), the Royal Australasian College of Physicians, I45 Macquarie Street, Sydney. 
37 Martin FIR. Unspeakably wonderful or dangerous remedy. The Introduction of insulin to Australia. In: Pearn J, editor. Milestones of Australian Medicine. Brisbane:Amphion Press; 1994. p. 217 ; $210-23$; 278-79.

38 Martin FIR. Unspeakably wonderful or dangerous remedy. The Introduction of insulin to Australia. In: Pearn J, editor. Milestones of Australian Medicine. Brisbane:Amphion Press; 1994. p. 215-16.

39 Wilkinson JF. The treatment of diabetes. Med J Aust 1923; 2: 102

40 Ingram WW. Synopsis of Lecture on Diabetes. Sydney, Kolling Institute, Royal North Shore Hospital, 1936 [Copy held in the Ingram Archives, R.A.C.P., Sydney].

4I Ingram WW. Diabetes in the Young. Sydney, s.p., 1938.

42 Ingram WW. Diabetic Diets. Sydney, Angus and Robertson, 1944.

43 Ingram W.Wilson. The Management of Diabetic Pre-coma and Coma. s.I. [Sydney], s.p.,s.d. [Copy held in the Ingram Archives, RACP, Sydney].
44 Ingram WW, Rudd GV. The diagnosis and treatment of diabetes and the use of high carbohydrate diets. Sydney:Angus and Robertson; 1933.

45 Ingram WW, Rudd GV. The diagnosis and treatment of diabetes and the use of high carbohydrate diets. Sydney: Angus and Robertson; 1943, reprinted 1944.

46 Australian Military Forces. Officer's Statement of Service in Australian Imperial Force. A.A. Form A.208. Lt. Colonel William Wilson Ingram, NX I 38384. Document No. 2654, Dated I 9 August 1944. [Copy held in the Ingram Archive, RACP, Sydney].

47 Vanderfield IR. 'DrW.Wilson Ingram'. Text of the Address given by Dr I.R. Vanderfield, General Medical Superintendent at the Memorial Service held in the Royal North Shore Hospital Chapel, Monday 6 December 1982. Archives, Library of the History of Medicine, Royal Australasian College of Physicians, Macquarie Street, Sydney 2000. p. 3.

\title{
UK CONSENSUS CONFERENCE APPROACHING THE COMPREHENSIVE MANAGEMENT OF ATRIAL FIBRILLATION: EVOLUTION OR REVOLUTION?
}

\author{
Thursday I March \& Friday 2 March 2012 \\ At the Royal College of Physicians of Edinburgh
}

This two-day UK Consensus Conference on Atrial Fibrillation has been convened by the Royal College of Physicians of Edinburgh. The key questions which the multidisciplinary panel, chaired by Dr Michael Rudolf, will aim to address from the written and oral presentations and submitted abstracts are:

- How can we best detect atrial fibrillation?

- Should the treatment of atrial fibrillation be targeted towards control of rhythm, rate or both?

- What is the most effective and safest delivery of thromboprophylaxis in atrial fibrillation?

- What are the differences between physician and patient expectation with regard to the management of atrial fibrillation?

Abstracts are invited for poster presentations and should be submitted by 31 October.

In association with:

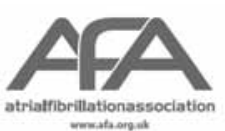

Royal College of General Practitioners
Details on registration and abstract submission can be obtained from:

http://events.rcpe.ac.uk/ events/I39/ uk-consensusconference-on-atrialfibrillation

Or by contacting: Margaret Farquhar, Consensus Conference Co-ordinator, RCPE, 9 Queen Street, Edinburgh EH2 IJQ Tel: +44 (0)।3। 2473636 E-mail: m.farquhar@rcpe.ac.uk 